Section III. Ecology and management of wild life in West Africa. (Covering wild life and vegetation, wild life and domestic animals.)

Section IV. The humid forests of West Africa, their original and present extent.

Papers are invited, and must reach the Conference Secretary before 3 I December 1958. Papers may be in either English or French, should not exceed 3,000 words, and must be prefaced by a brief summary. It is hoped to reproduce all papers for distribution during the Conference.

\title{
The African Studies Association in the United States
}

THE African Studies Association in the United States formally came into being at a conference held in New York in March 1957 (see Africa, October 1957, p. 401). During the intervening year the Board has met at intervals and reached a number of important decisions on the future policies of the Association.

The first issue of the African Studies Bulletin appeared in April 1958, and is designed to gather together some general information on the opportunities for the study of Africa in the United States and to acquaint its readers with the background of the African Studies Association. African Studies Programs of the following universities are given: Boston University; University of California at Los Angeles; Duke University Commonwealth Studies Center; Duquesne University; Hartford Seminary Foundation; School of Advanced International Studies of the Johns Hopkins University; Northwestern University; Roosevelt University; Food Research Institute of Stanford University; Yale University. It is expected that subsequent issues of the Bulletin will contain articles on topics of general interest in the field. An attempt will be made to keep the members of the Association informed of future academic visitors from Africa with their schedule of travel in the United States. News items of general interest in the field of African studies will also be included. It is planned that the Bulletin should appear quarterly in October, January, March, and May.

\section{The African Trade Development Fund}

The Government of Uganda set up the African Trade Development Fund in 1955 with the object of assisting Africans in trade, particularly in townships and major trading centres, by providing premises for rental. By this method the traders would be saved the need to invest their capital in a building and would, therefore, be able to devote it all to the speculative business of trading. At the same time Government would have a well-secured investment over which it retained full control. If a tenant failed, the investment would not suffer because the premises could be let immediately to another trader.

The scheme value of the fund is $£ 400,000$ to be received in annual instalments of which three have been paid so far to a total of $£_{17} 1,000$. The first phase of expenditure has been upon premises in the main townships. There are two reasons for this: (I) to encourage the integration of Africans and non-Africans in trade, and so help to dispel the idea held by many Africans that trading in townships was restricted to non-Africans; (ii) because capital assistance in respect of buildings is most needed in the townships where a premium has to be paid for a plot and buildings must be of a relatively high standard and value.

\section{Studia Universitatis 'Lovanium'}

THE Lovanium University at Leopoldville has, since 1957 , been publishing a series of scientific works under the title of Studia Universitatis 'Lovanium'. The series includes two 